\title{
CSAE WPS/2010-12
}

\section{Triggers and Characteristics of the 2007 Kenyan Electoral Violence ${ }^{*}$ \\ Stefan Dercon $^{\dagger}$ and Roxana Gutiérrez-Romero ${ }^{\ddagger}$}

\begin{abstract}
Following the 2007 disputed Kenyan Presidential election unprecedented levels of violence erupted across the country adding to the history of troubled elections in Africa. This paper offers quantitative and qualitative evidence on the incidence, impacts and issues that triggered electoral violence. Using two surveys conducted before and after the election we find that one out of three Kenyans were affected by the violence regardless of their ethnicity and wealth. The chances of being a victim of violence were higher in areas with land conflicts and where politicallyconnected gangs operated. Violence, which was mainly triggered by the perception that the election had been rigged, reduced trust and social capital among communities making violence more likely to reoccur.
\end{abstract}

Keywords: Voting, Electoral Violence, Rule of Law, Institutions, Africa, Kenya

Word Count: 10,884

\footnotetext{
* This paper was funded by the UK Department for International Development (DFID) as part of the Improving Institutions for Pro-Poor Growth (iiG), a research consortium aimed at studying how to improve institutions in Africa and South-Asia. The views expressed are not necessarily those of DFID. Thanks are due to the staff members of the Steadman group with whom we conducted our pre- and post-election surveys, extensive pilot work across Kenya as well as monitoring of the major media outlets in Kenya. A special thanks to Dennis Omondi who helped as field manager, to Emma Wanyoike and Stephen Kirugi for their work on monitoring the media information presented in this paper.

† Department of International Development, University of Oxford. 3 Mansfield Road, OX1 3TB, United Kingdom. Email: stefan.dercon@qeh.ox.ac.uk. Tel: +44 1865281822

‡ Corresponding author: Department of International Development, University of Oxford. 3 Mansfield Road, OX1 3TB, United Kingdom. Email: roxana.gutierrezromero@qeh.ox.ac.uk. Tel: +44 1865271913
} 


\section{Introduction}

Kenya was left with deep scars by the violence that erupted in the aftermath of the disputed Presidential election of 27 December 2007. In just a matter of weeks, Kenya was transformed from one of Africa's most stable democracies into chaos. Political and ethnic violence left more than a thousand people dead and over 350,000 people were forced to flee their homes as violence and machete-wielding gangs roamed the streets (Amnesty International USA, 2008; CIPEV, 2008). A coalition government headed by the former president Mwai Kibaki and Raila Odinga the two candidates claiming that each had won the presidential election- was agreed three months after the disputed elections. With the coalition agreement the electoral violence ceased, but the underlying triggers, extent and consequences of electoral violence in Kenya have still to be fully addressed.

Since the 1990s many African autocracies have engaged in various efforts towards democratization, Kenya not being the exception. Support for democratization has primarily being used as an instrument to achieve accountability, install broadly legitimate governments and help in mediating disputes among the diverse ethnic groups. These institutional efforts are expected to improve economic performance and reduce proneness to political violence (Fearon and Laitin, 2003; Carothers, 2007; Soudriette and Pilon, 2007). However, with a few exceptions the recent record of African elections has raised concerns that in ethnically divided societies, competitive electoral processes could in fact be destabilizing by widening existing divisions and deepening divisions between winners and losers (Bardhan, 1997; Syder, 2000; Wilkinson, 2004; Mansfield and Snyder, 2005, Eiffert, Miguel and Posner, 2007). Elections in poor African countries such as Kenya have tended to significantly increase proneness to civil war and various other manifestations of violence (Collier and Rohner, 2008). There are several likely reasons for the frequent failure of African elections such as having weak Electoral Commissions, inadequate judiciary and other institutions that can sustain democracy, but perhaps the main underlying cause is that no democratic means have been found to mediate the struggles over access to land and the 
resources controlled by the state (Bratton, 2008; De Smedt, 2009; Peters, 2009). Given these high stakes, politicians resort to a variety of means including vote buying, intimidation, electoral violence (Lindberg, 2003; Wilkinson, 2004; Schaffer, 2007; Vicente, 2007; Bratton, 2008) and other methods of manipulation such as the old trick of stuffing ballot boxes, tampering with vote tallies and ballot stealing (Throup and Hornsby, 1998).

The purpose of this article is to assess the incidence, impacts and the dynamics of the 2007 electoral violence. The article seeks to provide light to understanding of who was affected by violence, what sort of issues triggered the violence and what were the consequences left by the electoral violence at community level. The majority of studies of conflict have tended to focus on cross-country comparisons, or in the case of country studies, to gather scant evidence, often anecdotal, which limits the understanding of what are the risk factors for violence. This paper aims to contribute to the emerging field of micro-quantitative studies on conflict (Collier and Vicente, 2008; Kalvas, 2008; Barron et al., 2009; Bellows and Miguel, 2009) by assessing the individual and local factors that increased the risk of being a victim of electoral violence. The quantitative and qualitative data used allow us to draw a national representative perspective, with enough data at small area-level, to be able to assess how violence emerged and affected people at community level. Although the paper focuses on the experience of Kenya, its findings have broader relevance as they reveal what sort of institutional failures led to violence and reflect policies that could be taken to reduce the recurrence of civil conflict.

To explore our research questions two surveys were undertaken, one just two weeks before the December 2007 general elections and a second one reinterviewing previous respondents in August of 2008. The pre-election survey asked about voter intentions, votebuying, intimidation and violence activities among other themes. The data are based on a nationally representative survey. The post-election survey revisited previous respondents to find out about their experiences in the aftermath of the election, their expectations from the new coalition government and whether their views had changed regarding trust among Kenyans, 
democracy, rule of law, among other issues. As the surveys were conducted right before the elections and some time after the elections they provide a unique opportunity to explore how political perceptions changed in the aftermath of the elections and how our respondents were affected by violence and other non-democratic practices. Information was also collected on the poverty at constituency level ahead of the elections and earlier.

As we follow our previous respondents of December 2007 over time rather than drawing a complete new sample of respondents we are able to analyze how electoral violence affected them. To complement the information on when and where electoral violence originated and how rapidly this evolved over time we also monitored the major media outlets across the country (local ratio stations, national newspapers and TV channels) on a daily and 24 hours basis from 1 December 2007 until 31 March 2008. Collating the panel-survey data and the instances of electoral violence reported in media helps us build a more comprehensive picture of how violence emerged, where and when it spread and what consequences violence and other electioneering practices had on Kenyans.

According to the self-reported incidence of violence in our surveys, violence affected one out of three Kenyans in terms of personal injury, being displaced from home, destruction of property, loss of jobs or earnings or having a friend or relatives that died in the elections. The likelihood of being a victim of violence was not affected by the respondent's ethnicity or wealth but by where respondents lived. Respondents living in urban areas and in areas which had suffered land disputes before the election had a higher likelihood of being victims of violence. Violence was directly instigated by political actors and by politically connected gangs such as Mungiki even before the elections. According to unsubstantiated reports in the media the police and politically connected gangs contributed to the majority of the killings observed during the post electoral violence (Ohito and Obonyo, 2010). Nonetheless, the majority of respondents believe that violence was triggered mainly by the perception that the election had been rigged. 
The ordeal of the disputed election reduced trust across ethnic groups, a key element of social capital among communities. International experience has shown that in situations where (ethnic) groups distrust each other and are afraid of being victimized, this fear might drive them to resort to violence first in a preemptive move to minimize damage (Bardhan, 1997). Taking into account that having experienced conflict in the recent past is a good predictor for future conflict (Collier et al. 2008), Kenya is at risk of experiencing violence in the forthcoming 2012 general elections if institutions are not strengthened to cope with the underlying grievances, the need for justice and the mistrust among ethnic groups.

Although much of the electoral violence ended with the formation of the coalition government in Kenya, as it did in the recent case of Zimbabwe, coalition governments formed after disputed elections can set a misleading precedent to the future of democracy in Africa. Coalition governments are not a substitute for democracy and as our survey in Kenya showed, it is ultimately not what people want (at least not at the time we conducted the survey, six months after the formation of the coalition government).

The article proceeds as follows: In the next section, we provide a brief summary of the Kenyan history towards democracy and the 2007 political campaign. Section three presents some highlights of the survey and media data, focusing on when and where violence occurred, how people were affected, who were the victims and what are the perceived triggers of violence. Section four expands on this analysis by exploring in more detail the profile of victims of violence and how violence changed some of Kenyans' perceptions, based on multivariate analysis. The conclusions and discussion of the results are presented in section five.

\section{Kenyan Elections}

Kenya gained independence from Great Britain in 1963 and from then up until 2002 was ruled out by the political party Kenya African National Union (KANU). KANU's dominance was achieved by banning opposition parties in 1969 leaving Kenya a de facto one-party state to a de 
jure one-party state when a constitutional amendment in 1978 ruled that no other party was able to contest in the elections. In 1991 after much pressure from Kenyan activists and the international community multi-party elections were re-introduced. Several opposition parties emerged (FORD Kenya, FORD Asili, Democratic Party, Social Democratic Party, National Development Party of Kenya and other smaller parties). Nonetheless KANU remained in power winning the general elections of 1992 and 1997 amid violence and allegations of electoral irregularities. Much of the violence occurred during the pre-elections period and was concentrated in the Rift Valley and Western provinces and according to Kagwanja (2003) apparent local "Kalenjin warriors" attacked the homes and farms of migrant non-Kalenjin groups. The government described the violence as ethnically motivated clashes that erupted spontaneously as a result of multi-party politics. Analysts though, argued that politicians instigated the violence as a tool for winning the elections. People's need for land was exploited by some politicians to instigate violence, especially in the Rift Valley, as it has happened in other African troubled elections (Peters, 2009). Kagwanja (2001) argues that the Kalenjin and Maasai ethnic groups were allowed to occupy land abandoned by displaced groups to ensure the political alliance of these groups and to prevent them from joining opposition parties. The Kenyan elite aiming to suppress opposition political parties also recruited and sponsored 'tribal militias' and gangs for them to terrorize and instigate ethnic violence in the same vein as other African countries have done such as Cameroon, Malawi, Nigeria, South Africa and Sudan (Kagwanja, 2003). Hence, contrary to the government's description of the violence as 'spontaneous ethnic clashes', the evidence suggests that much of the violence was in fact sponsored by the State whose actions did little to contain it (Human Rights Watch, 1993, p.1).

The Kenyan Human Rights Commission (2001) estimates that state-sponsored or statecondoned violence killed 4,000 people and displaced 600,000 others over the period 1991-2001. Much of this violence was sponsored in the Rift Valley and in urban areas, especially in Nairobi where the opposition held sway since 1992 (Kagwanja, 2003). The end result of this violence was 
the retribalization of politics and the erosion of civic nationhood (Kagwanja, 1998, 2003; Throup and Hornsby, 1998).

In the general elections of 2002, all the opposition parties for the fist time united under the National Rainbow Coalition (NARC) and behind a single presidential candidate, Mwai Kibaki. Kibaki won the presidential elections by defeating KANU’s presidential candidate Uhuru Kenyatta. Mwai Kibaki's Presidential election success in 2002 -declared free, fair and the most peaceful elections that Kenya has had in recent years by international observers- was hailed at the time as a step forward for Kenyan democracy. The democratic achievement was much owed for having formed a multi-tribal NARC coalition, unlike the previous multi-party elections where political parties formed seeking to target a specific ethnic group (Oyugi, 1997). It also helped that the two presidential candidates (of the NARC and KANU parties) were from the same ethnic group (Kikuyu). In that the election focused on which party would bring the most prosperity to the country forgetting tribalistic agendas.

Kibaki came to power promising to turn the economy around, to introduce free primary education, to deliver a new constitution within 100 days of his presidency and to end corruption and tribalism. President Kibaki's administration delivered to Kenya a booming tourism industry, economic growth increased from a rate of close to zero to more than $6 \%$ annually and free primary school education was introduced. Less progress was achieved in tackling corruption, widespread poverty, simmering ethnic/land tensions and in delivering a reformed constitution.

Kibaki's defeat in the 2005 Referendum on a revised constitution failed to reach a consensus on how Kenya should be run. Among the policy issues in the referendum were the settling of land rights, the sharing of political power among ethnic groups -possibly between a President and Prime Minister- and how to decentralize resources across regions.

The failed Referendum also split Kibaki’s cabinet. Roads Minister Raila Odinga and Environment Minister Kalonzo Musyoka, who led the group against the approval of the referendum, formed a new opposition political party, the Orange Democratic Movement (ODM). 
In September 2007 the seventy-five year old President Kibaki declared that he would stand again in the presidential elections, backed by a new political alliance - the Party of National Unity (PNU). Among Kibaki’s supporters, once his political rivals, were former president Daniel arap Moi and Uhuru Kenyatta, leader of the former ruling party KANU. KANU having failed to gain sufficient backing to mount a presidential bid left Kenya for the first time with a presidential election without KANU contesting it. The media blamed tribal loyalty as the main factor for this alliance. Odinga blamed President Kibaki of blackmailing former president Moi over possible charges of corruption against him. Regardless of the reason for the Kibaki-KANU alliance, the ODM was left with major chances of contesting the elections. But, just four months ahead of the elections the ODM split into two fractions as they failed to select a presidential candidate. So Kibaki faced a weakened opposition led by Raila Odinga, backed by ODM and Kalonzo Musyoka, backed by the new fraction ODM-Kenya.

\section{Monitoring 2007 Political Campaign}

To assess the nature of electoral campaigning and violence we requested the Steadman Group, a private company with the most experience in monitoring media in Kenya, to track political advertising, political campaigning as well as incidents of electoral violence across the country. Twelve major media outlets were monitored on a daily and 24 hours basis from 1 December 2007 until 31 March 2008. Local radio stations and leading national newspapers and TV channels were monitored enabling us to have a broad picture of how political campaigning evolved at both local and national level. The radio stations monitored were the KBC radio service, Citizen Radio, Inooro FM, Kass FM, Ramogi FM, Mulembe. The TV stations monitored were KBC TV, CTV, NTV, KTN and the newspapers monitored were the Daily Nation and the Standard.

The political campaigning centered around the politicians’ track record, trust, promised policies but also on tribalism. In contrast to the 2002 election, the 2007 elections were characterized by political parties pursuing sectarian agendas and accusing each other of using ethnicity for political purposes. For instance, Odinga's political manifest argued "Ethnicity is a 
national disease knowing no regional boundaries and not confined to any one community. It rules our national politics and divides us unnecessarily. The Kibaki Government has compounded the ethnicity factor and deepened ethnicity in our public service by appointing people from his own community. Thus the reorganization of the Government was dictated by prejudice and not equity...The Kibaki government's kazi iendelee means let the status quo prevail - public jobs for the few and not the many.” (ODM 2007, p. 16).

\section{Pre-Electoral Violence Reported in the Media}

To assess how peaceful the political campaigning was we reviewed all incidents of electoral violence reported in the twelve media outlets monitored (local ratio stations, newspapers and TV stations) from 1 December 2007 until 31 March 2008. By electoral violence we refer to all acts of violence that were politically related as recorded in the media. The number of reports investigated were cross checked (by date, location and content) across the media houses monitored to avoid repetition or duplication of incidents. ${ }^{1}$ Although this media monitoring analysis cannot conclusively ascertain that the events reported were indeed accurate or free of editorial interference, the overall death toll resulting from electoral violence according to our analysis of media reports $(1,169)$ approximates the number in the reports of Amnesty International and the official number $(1,174)$ of people killed by electoral violence (41 deaths in pre-electoral violence according to police reports plus 1,133 of deaths in post-electoral violence according to the Waki Report by CIPEV (2008)).

There were a few incidents of electoral violence before the Election Day. The great majority of them occurred during political rallies and were concentrated in specific small towns. This pre-electoral violence was manifested in the disruption of campaign rallies, threats of

\footnotetext{
${ }^{1}$ While CTV, Ramogi FM, Mulembe and Citizen Radio are affiliated to the same media house (Royal Media), and KBC radio and KBC TV belong to the state broadcaster, reports were cross checked to avoid repetition of incidents while logging the reports.
} 
violence to aspirants and party supporters, distribution of hate campaigns via leaflets and SMS that sought to incite violent prejudice against members of rival parties and direct violence on candidates and supporters including reported killings. Campaign-related ethnic violence was also reported in the Rift Valley as ethnic groups clashed within Molo, a district that reports cases of ethnic violence every election year as political rivalry and aggression is transferred to land ownership issues.

Forty one people died as a result of pre-electoral violence in December. According to the media (and police reports) 25 of these deaths took place during campaign rallies, the highest death toll caused by campaign rallies in Kenya. Since the great majority of deaths (25) occurred in the Molo district and not across the country the electoral campaign was perceived as free and fair by international observers and by the media. The scenario changed drastically in the period immediately after the 27 December 2007 general elections and the period following the announcement of the presidential results on 30 December. Before describing the events of postelectoral violence we present next the voting intentions and electoral irregularities according to our survey respondents.

\section{Electoral Irregularities: Pre- and Post-Electoral Surveys}

Two weeks ahead of the elections we conducted a detailed survey of voter intentions, attitudes towards violence, socio-economic characteristics of Kenyans among other issues. The data are based on a nationally and regionally representative sample of 1,207 Kenyans aged 18 and over who were interviewed in 76 out of the 210 constituencies with a margin of sampling error of $+/-$ $3 \%$ at a 95\% confidence level. The sample captures the rural/urban split consistent with the most recent Kenyan census that shows that $65 \%$ of respondents live in rural areas and the remainder in urban areas. The ethnic distribution of the sample respondents also matches that of the national population. We conducted a second survey in August 2008, revisiting previous respondents to find out about their experiences in the aftermath of the election, their expectations from the new 
coalition government and whether their views had changed regarding trust among Kenyans, democracy, land conflict, among other issues. We managed to re-interview $60 \%$ of our previous respondents. ${ }^{2}$ In order for our post-electoral survey to be comparable to our previous survey we replaced respondents that could not be found for new ones that had the same gender, education (defined as completed primary or less, or more than completed primary) and living in the same constituency as the respondent replaced. In addition if the respondent that could not be tracked back was a Meru, Kikuyu, Luo or Luhya the respondent was replaced with a person of the same ethnicity, gender, education who lived in the same constituency. We replaced respondents with new ones living in the same constituency, as our extensive pilot work in the worst areas affected by violence (Rift Valley, Nyanza and Nairobi) suggested that the great majority of displaced people moved within the same constituency to areas where they had relatives or to neighborhoods where there were more clusters of people from their ethnicity. Respondents of Meru, Kikuyu, Luo or Luhya that could not be tracked were replaced with respondents of the same tribe as our pilot work suggested that these were the ethnic groups worst affected by violence and above all by displacement. The main characteristics of both surveys respondents are listed in Table (1).

At the time of our pre-election survey, most respondents (98\%) claimed that they would cast their vote in the following general elections. The two main presidential candidates, the then incumbent president Mwai Kibaki and Raila Odinga were in a close race with $39.1 \%$ of respondents intending to vote for Kibaki and $46.6 \%$ for Odinga. Classifying voter preferences for a presidential candidate and voters' ethnic group shows that there is unison in the voting patterns

\footnotetext{
${ }^{2}$ This apparently high attrition rate is to a considerable extent caused by problems with the tracking details in the first round of the survey. In December 2007, we never intended to revisit the sample, as the postelection violence came as a surprise to us as to most observers. As a result, when conducting the new round of the survey in August 2008, we lacked often the necessary details for successful tracking. Displacement due to the violence cannot be ignored as a possible reason for not being able to re-interview a respondent, leading to the replacement rules as described in the text to minimize any bias arising from attrition.
} 
among most ethnic groups. The three main presidential candidates, Kibaki (of Kikuyu ethnicity), Odinga (of Luo ethnicity) and Kalonzo (of Kamba ethnicity) were overwhelmingly supported by the people from their own ethnic groups (as shown in Table 2). Other ethnic groups that did not have a major presidential candidate contending in the election seem to have voted for one of the candidates in a block: The Luhyas and Kalenjins primarily supported Odinga, while the Merus and Embus supported Kibaki. Given the close proximity in the voter's intentions any of these two candidates could have won depending on voter turnout.

\section{Who won the presidential elections?}

The elections were held on the 27 December 2007. Kenyans went to the polls in record numbers, some waited for hours in lines that were miles long (Gettleman, 2007). A day after the election, the first batch of results showed Raila Odinga with a clear advantage in the presidential race, leading by more than one million votes. The ODM declared victory for Raila Odinga on 29 December but as more results were announced on the same day, the lead that Odinga had shrunk to only 38,000 votes with $90 \%$ of the votes counted. Against the predictions of opinion polls and the early counts of the votes, the Election Commission of Kenya found Mwai Kibaki the winner of the presidential election on 30 December, placing him ahead of Odinga by 232,000 votes. That is with $51.3 \%$ of the votes to Kibaki and $48.7 \%$ for Odinga and with a $69 \%$ of voter turnout. Following the disputed Electoral Commission's declaration, Kibaki was right away sworn in for his second term. Cries and doubts for a stolen election were immediately shared by the ODM party and international electoral observers.

The ODM party pointed out that a sign of fraud was the fact that the MPs contending for the ODM (the party supporting Raila Odinga) had won 99 seats versus the 43 seats won by the MPs of the PNU (the party supporting Mwai Kibaki) in the general elections. Although one could argue that people voted strategically for Mwai Kibaki (the PNU party) for the presidency and for MPs backed by the ODM, our survey shows no sign of such strategic voting. The majority of those who claimed would vote for Raila Odinga for president also claimed that they would vote 
for MPs contending for the ODM (94\%). Similarly those who claimed that they would vote for Mwai Kibaki supported MPs running for the PNU (92\%).

On 2 January 2009 Samuel Kivuitu, the Chairman of the Electoral Commission, admitted "I do not know whether Kibaki won the election" (Ongiri, 2008). Kivuitu also revealed that he was put under pressure by "some PNU and ODM-Kenya leaders" by calling him frequently and asking to announce the results immediately. ${ }^{3}$ Kivuitu agreed to take the presidential election winner's certificate to the State House after "some people threatened to collect it...". To Kivuitu’s surprise "the Chief Justice was already there ready to swear-in Kibaki". Kivuitu agreed to announce the results because the Electoral Commission had no legal mandate to investigate complaints raised by the opposition immediately. It was a matter for the courts to investigate the irregularities.

With the information available in our surveys it is impossible to dwell on the irregularities mentioned by the opposition or electoral observers. But as shown in Table (2) both our pre- and post-electoral surveys suggest that Raila Odinga was the favorite to win among the electorate, more evidently so in the post-election survey.

\section{When and where electoral violence spread?}

Within hours of the announcement that Mwai Kibaki won the presidential election violence spread across much of the country. However, not all violence erupted 'spontaneously'. Our preelectoral survey shows evidence of ethnic and politically instigated violence even before the elections. Roughly $30 \%$ of respondents claimed that 'Political representatives openly advocated violence in their communities before the election'. This figure remained practically unchanged after the elections. Gangs connected with politics were frequently mentioned too. Before the elections $20 \%$ of respondents reported that they had heard frequently about gangs connected with politics in their community. This figure went up to $31 \%$ after the election. Similarly $20 \%$ reported

${ }^{3}$ The ODM-K had apparently an agreement with the PNU which stated if Kibaki was to be re-elected president, Kalonzo would become the vice-president of Kenya. 
having heard frequently of ethnic violence in their community before the elections, and this figure went up to $35 \%$ after the elections.

Also there were plenty of irregularities before the elections such as vote-buying, having suffered intimidation from members of political parties and land disputes. Specifically, one out of two respondents experienced attempted vote buying and almost one out of six experienced intimidation. Five percent of respondents "Had land disputes over the year ahead of the election" and similarly 5.3\% accepted to be "Settled in an irregular land scheme". Before the elections there was widespread fear that violence would erupt, roughly $50 \%$ of respondents were afraid that electoral violence would spread to their constituency before the elections, and this figure went up to $58 \%$ after the elections.

According to the media reports, after the elections and especially once the results were announced, the opposition party supporters went on an unprecedented level of 'orgy of violence' which lead to counter attacks and 'revenge killings' (Otieno, 2009; The Standard, 2009). Violence spread to five out of the eight provinces in Kenya (Nairobi, Nyanza, Rift Valley, Western, Coast and Central). The bulk of the violence was reported in Nairobi and the Rift Valley, due to the proximity between feuding ethnic communities in these places. From the 1st to the 10th of January violence was predominantly in Nyanza, Western, North and South Rift and the Nairobi slums. In Nyanza and the Western provinces most of the deaths reported were from police related shootings: 56 people were reported shot by the police in the first week in Kisumu, with over 46 people killed in Eldoret in a single incident by raiders in the first week.

January was dominated by demonstrations with the slogan 'No Raila, no peace!' as the ODM called several times for nationwide demonstrations aimed at forcing the elected president to resign (De Smedt, 2009). In the Rift Valley revenge attacks which began in Nakuru in late January rose in intensity and spread along the main highway to affect the towns of Naivasha and also Limuru and Kikuyu in the Central province. In Nairobi, the police tried to stop demonstrations with water cannon, teargas, arrests and barricades between slums and wealthier 
suburbs resulting in more clashes (De Smedt, 2009) and more alleged cases of people killed by police bullets.

On 1 February, ex-UN Secretary General, Kofi Annan announced that Kibaki and Odinga had agreed on an agenda for peace talks. On 28th February, after weeks of bloodshed, international pressure and tense negotiations the important handshake was finally reached. President Mwai Kibaki and opposition leader Raila Odinga put the disputed elections behind them and agreed to share power. Kibaki was to remain the elected President, Kalonzo the VicePresident and Odinga was to be appointed Prime Minister -a post which did not exist then under the Kenyan constitution.

With the peace agreement violence also swiftly ceased (despite that, only $20 \%$ of respondents agreed that forming the coalition government was their "Preferred choice to end the disputed presidential elections"). The monitored media sources account for 1,127 people killed because of electoral violence from the Election Day 27 December 2007 until 29 February 2008. The official post-electoral death toll over the same period was 1,133 and 3,561 people injured according to the Waki Commission in charge of investigating the electoral violence (CIPEV, 2008 p. 305 and p. 331). ${ }^{4}$ In total, we found 1,169 people killed because of electoral violence from 1 December 2007 until the 23 March 2008. Among the dead were two recently elected MPs (from the ODM party).

Media reports, such a the one by Ohito and Obonyo (2010), state that an estimated 1,000 deaths are linked to the Kenyan Police alone and hundreds are attributable to politicallyconnected gangs such as Mungiki. These reports might well over-represent the extent to which the police is responsible for the casualties. For instance, the Waki report finds that $35.7 \%$ of the

\footnotetext{
${ }^{4}$ The Commission estimated the death toll using medical and post-mortem reports, police returns, reports received from private hospitals and institutions and various witness statements, depositions and oral testimonies. The estimate of people injured refers to the people who attended hospitals and other established institutions but who did not died.
} 
casualties can be directly linked to the police (405 out of the 1,133) as they died because of gun shots wounds (CIPEV, 2008p.331).

Electoral violence in addition to claiming lives, injuring people and displacing over 350,000 people also affected the economy. The tea and flowers exports industries, in which Kenya is a main leader in the world market, were severely hit because their workers were displaced far from the fields. Ksoll et al. (2009) estimate that flowers exports were reduced by $38 \%$ during the first quarter of 2008 because of electoral violence directly. The FAO reported less than $10 \%$ of land had been prepared for planting season by January 2008 . Normally, at least $80 \%$ would have been planted by that time (Kimani, 2008). The tourism industry, the second highest foreign exchange earner after horticulture, was also affected as the violence occurred during what is typically the Kenyan peak holiday season. Foreign offices advised not to travel to Kenya unless absolutely essential, leading to a steep fall in number of tourists visiting the country. According to the Kenyan Tourist Board occupancy rates dropped to an average 30\% compared to $86 \%$ in the year before. As a result tourism revenues plummeted 54\% from 2007 in the first quarter of 2008 (Holland, 2008). Professor Terry Ryan, adviser to Kenya's Central Bank, estimated that the rate of growth of the Gross Domestic Product (GDP) more than halved from the $6 \%$ before the election to $2 \%$ because of the electoral violence (Crilly, 2008). Kenya Manufacturing Association Chairman, Steven Smith, estimated that the industry's production reduced by $35 \%$ in January and a further $20 \%$ by April. He also estimated a $3 \%$ loss of growth in GDP, due to loss of jobs, business opportunities and the impact that the Kenyan crisis had in the region’s economy (Kimani, 2008).

Abe Selassie from the International Monetary Fund representative in Uganda argued that the Kenyan political crisis had exposed the East African region's “overreliance” on Kenya's transport infrastructure, especially the Mombasa port (Kimani, 2008). The numerous blocked roads and vandalized rail lines in Kenya affected significantly the economy of the region. Fuel 
prices rose throughout East Africa. The UN's Office for the Coordination of Humanitarian Affairs (OCHA) estimates that fuel costs in Uganda, Eastern Democratic Republic of Congo and Burundi rose by up to $50 \%$ as a consequence of the Kenyan crises. Fuel costs more than double in Rwanda causing shortages and prompting the government to institute fuel rationing. Trade networks were also disrupted especially for the landlocked economies of Uganda, Rwanda and Burundi, South Sudan and the Eastern Democratic Republic of Congo which rely on trade through the Kenyan port of Mombasa. ${ }^{5}$ According to Juma Mwapachu, the Secretary General of the East African Community "Trade flows have been negatively affected and so have exchequer and business revenues...We can only promote and attract investments sustainably, as well as assure effective intra-regional trade, if we have enduring peace and stability." (BBC News, 2008).

\section{To what extent and how were people affected by violence?}

Apart from the obvious impact that the Kenyan political crisis had on the macro-economic level, the crises had consequences at the micro-level. Here we explore the extent to which, Kenyans, were affected on the ground. To explore whether our survey respondents were affected by the outbreaks of electoral violence we asked "Were you personally affected in the outbreaks of violence after 2007 in any of the following ways?” Twenty-nine percent of respondents reported a specific personal impact after the elections, that is in terms of personal injury, being displaced from home, destruction of property, loss of jobs or earnings or having a friend or relatives that died in the elections. Figure (1) shows that about 3\% of respondents claimed that their houses were destroyed in the outbreaks of violence and $7 \%$ of respondents claimed that their houses were damaged.

\footnotetext{
${ }^{5}$ More than $80 \%$ of Uganda's imports pass through the port of Mombasa, as do almost all of Rwanda's exports. According to the Uganda Manufacturers Association manufacturers had lost \$43 USD million because of the delays, destruction of goods and slowed production caused by the Kenyan crisis (Kimani, 2008).
} 
A further question asking directly whether the respondent had a family member that died because of the electoral violence revealed that $4.6 \%$ of respondents had suffered from this event. This figure needs to be interpreted carefully as our respondents might have understood the definition of "family member killed" in a loose term, such as having close friends or having heard of someone in their community being killed.

One out of the 1,207 respondents interviewed in December 2007 unfortunately died and according to relatives the respondent died as a result of the electoral violence. Roughly $2 \%$ of respondents claimed that they "Moved to a camp for displaced people in response to the incidents of electoral violence?” (Figure 2). Also a few others (1\%) moved to neighboring countries such as Tanzania.

As Figure (3) shows the provinces with the highest concentration of victims of electoral violence according to our post-electoral survey are in the Rift Valley, followed by Eastern, Nyanza and Western. This distribution of incidence of violence coincides with the one mentioned in media reports.

\section{What issues triggered electoral violence?}

We asked respondents the open question "What triggered electoral violence in your neighborhood?” The majority of respondents (42\%) think election irregularities and a weak Electoral Commission were the main factors that triggered electoral violence. Of course this does not necessarily mean that this was the cause of violence, but just what ignited violence. Only $10 \%$ of respondents report to believe that electoral violence was triggered by tribal conflict and roughly a third of respondents do not know or did not want to state what the main trigger of electoral violence was.

\section{Consequences of violence}

The events that followed the general elections of 2007 might have affected political behavior and many of Kenyan's views such as support for democracy. Perhaps surprisingly we found that in both surveys the majority of respondents (70\%) reported democracy as the most preferable type 
of government. However, the perception that Kenya is a full democracy changed. In December 2007, 20\% of respondents believed that Kenya was a fully democratic country. That perception is now shared by only $6 \%$. The majority of people (86\%) still believe that Kenya is a democratic country, although with problems.

To elaborate on Kenyan's view on democracy respondents were asked about their trust in elections. There is a statistically significant increase from $10 \%$ to $26 \%$ of respondents preferring other methods for choosing leaders. In other words, Kenyans have faith in democracy, but not in elections. Of course, democracy is not just about holding elections. Institutions are needed to sustain democracy. Therefore it is important to look at how much institutions are trusted and how they are regarded. The surveys reveal that the Kenyan Electoral Commission has lost its credibility. In December 2007, 11\% of respondents claimed "Not to trust at all the Electoral Commission”. That perception increased to 50\% after the election. In general people lost trust in the ECK regardless of who they claimed they had voted for president in the elections of 2007 or whether respondents had been victims or not in the outbreaks of the electoral violence.

President Kibaki has also lost trust since December 2007 as a result of the outbreaks of violence. In December 2007, 33\% of respondents claimed to “Trust a lot president Mwai Kibaki”. This figure showed a statistically significant drop to $21 \%$ by August 2008. At first glance these results might indicate that there is a generalized loss of trust in institutions. However, those who "Trust the parliament a lot" increased from $8 \%$ to $17 \%$, which might be partly due to the fact that the parliament had a high turnover rate, with $80 \%$ of incumbent MPs not succeeding in their reelection bid.

Perhaps the most dramatic change after the elections is the deterioration of trust and in general of social capital across ethnic groups and communities. By social capital we mean the shared trust and norms that arise from informal social networks which have a consequent effect on expectations and behavior (Durlauf and Fafchamps, 2004, p. 5). Figure (4) shows that trust has significantly declined, especially across ethnic groups. Pre-election the trust levels were not 
particularly high among groups (only 8\% claiming they "Trust a lot people from other ethnic group" in December 2007). Post-election roughly 50\% of respondents claimed that their "Trust towards people of other ethnic groups was worse than in December 2007”. Nineteen percent of respondents claimed that they "Lost trust towards their own ethnic group since the elections".

The post-electoral survey also reveals that the loss of trust across ethnic groups has had some deeper consequences in informal economic networks. Many socio-economic relationships are based on trust, and not simply on economic interests. Clear examples of this type of trustbased relationships are economic exchanges, that is how much one does business with others. According to the post-electoral survey, 33\% of respondents claimed that the extent to which they "Do business with people from other ethnic groups had worsened since the elections".

International experience has shown that when groups distrust each other and are afraid of being victimized, this fear might drive them to resort to violence first in a preemptive move to minimize damage (Bardhan, 1997). This might explain for the animosity towards violence observed after the disputed elections. In December 2007, 12\% of respondents answered that it is "Sometimes necessary to use violence in support of a just cause", this figure went up to $21 \%$ by August 2008. In other words today, one in four Kenyans say that violence is justified. The survey also shows that Kenyans are divided on whether amnesty should be given to those who were

involved in the outbreaks of violence. Roughly $43 \%$ of respondents disagree with granting amnesty, whilst $45 \%$ agree amnesty should be given.

\section{Econometric Analysis: Profile of victims of violence}

In this section we assess which are the main individual and local variables which increased the chances of being a victim of post-electoral violence. We explore this profile of the victims of post-electoral violence using a multivariate analysis and the post-electoral survey. In the analysis we use the 1,207 interviews conducted in August 2008, that is the 667 reinterviews of the original respondents whom we tracked over time and the 540 interviews of the replaced respondents. 
Based on the quantitative and qualitative analyses of the electoral violence in the 2007 elections (and of the ones of 1992, 1997 and 2002) we identified four main variables that might be particularly correlated to the likelihood of being a victim of electoral violence. The first relates to the importance of land disputes in getting caught in electoral violence. The first hypothesis to test is that people who had land disputes were more likely to be victims of post-electoral violence. This seems to have been the case in previous multi-party elections in Kenya and in other African countries (Bardhan, 1997; Kagwanja, 2003; Peters, 2009) and our quantitative evidence suggest that might have been the case in the 2007 elections as well. Without specifying the mechanisms, of whether people with land disputes instigated or were caught in violence, we expect that people whom had land disputes ahead of the election were more likely to having been victims of postelectoral violence. The second main hypothesis is that people living in areas where gangs politically connected operated were more likely to be victims of post-electoral violence. The rationale is that these gangs were ready to instigate violence and attack people increasing the chances of being a victim in areas where these gangs operated. Since the 1990s these gangs have operated in urban areas, particularly in slums in Nairobi (Anderson, 2002; Kagwanja, 2003; De Smedt, 2009), so we would expect people living in these areas to be more likely victims of violence. The third hypothesis suggests that poverty, as a proxy of relative deprivation and grievance, motivated people to be violent. There is international evidence that grievances in terms of resource deprivation, and poverty, can lead to rebellion, protest and civil conflict, especially in Africa (Addison, 1998; Collier, 2000; Collier and Rohner, 2008). If this is the case in Kenya, then we would expect that the people most affected by violence were either the poor or those living in poorer areas. The fourth main hypothesis we explore is whether the chance of being a victim of violence is correlated to being member of a specific ethnic group. If it is true that one group tried to cleanse another, we would expect different likelihoods of being victims of violence by ethnic groups. It is of interest to assess whether people living in communities which are more ethnically mixed had a higher risk of being victims of violence. Although there is mixed international 
evidence on this (Fearon and Laitin, 2003), some studies have found that typically ethnically mixed societies are more likely to engage into conflict (Gurr, 2000). The history of elections in Kenya has shown that politicians have tapped into people's ethnic differences with the purpose of dividing the electorate and conquering political rents. So it is of interest to assess whether 'this divide and conquer policy' increases the chances of being victim of violence in relatively low or high ethnically mixed communities.

To assess the profile of victims of violence we use the probit model shown in equation (1) using as dependent variable the respondent's answer to "Were you personally affected in the outbreaks of violence after 2007 in any of the following ways?: Personal injury, destruction of home, being forced to leave home, damage to personal property, loss of a job, destruction/closure of business, loss of earning from business, friends or relatives died." In the probit model we control for the respondent's characteristics, represented by vector $X_{i}$, the province where the respondent lived right before the elections $\mathrm{P}_{\mathrm{i}}$, and the degree of ethnic diversity in the area where the respondent lived right before the elections ETHNIC $\mathrm{C}_{\mathrm{i}}$.

$$
\operatorname{Pr}\left(\text { victim of electoral } \text { violence }_{i c}=1\right)=\Phi\left(\alpha+X_{i} \beta+P_{i} \eta+E_{T H N I C} \delta\right),
$$

where $\Phi($.$) is the cumulative distribution function of the standard normal distribution and$ $\alpha$ is a constant. Since there are no publically available measures of ethnic diversity at district level in Kenya, we measure ethnic diversity using our pre-electoral survey, and the Ethnolinguistic Fractionalization (ELF) index in eq. (2), used in much of the analysis of ethnic diversity and conflict (Alesina et al. 2003).

$$
\text { Ethnic Diversity }=1-\sum_{j=1}^{J}\left(\frac{n_{i j}}{N_{i}}\right)^{2}
$$

where $\frac{n_{i j}}{N_{i}}$ is the proportion of people belonging to ethnic group $j$ in district $j$. This index of ethnic diversity takes the value of zero if all the population in the district belongs to the same ethnic group and increases in value the more ethnically diverse the population is in the district. In our 
sample, the majority of districts sampled had respondents belonging to more than one ethnic group (74 out of 77) so the ELF index ranges from zero to 0.8 .

Table (3), under column (1), presents the regression coefficients of the individual and local factors that influenced the probability of being a victim of electoral violence. The coefficients reported are marginal effects and the robust standard errors are clustered at constituency level. The respondents who were more likely to have been victims of electoral were those who reported "Had land disputes in the year previous to the 2007 elections" (increasing the probability of experiencing violence by 18\%), living in urban areas (increasing it by $7 \%$ ) and respondents who claimed "There where organized gangs connected to politics operating in their communities before the elections" (which increases the probability of violence by 13\%). This evidence is in favor of our first and second hypotheses that electoral violence was infused by political actors and by land disputes.

Respondent's wealth level was not a contributing factor for being affected by violence. We assessed a respondent's wealth level by constructing a wealth-asset index based on the responses to "from the following list which of these things does your household own?". The list of things includes 15 possible durable assets ${ }^{6}$, which we used to construct a normalized wealthasset index ranging from 0 (respondent not owing assets at all) to 1 (owning all 15 listed assets). Table (3) shows that the probability of being a victim of electoral violence was not statistically significantly affected by wealth. We also used the poverty level where the respondent lived (at constituency level) reported by the Kenyan Bureau of Statistics in 2006. The marginal effect of poverty 0.001 (standard error of .091 and not shown in the table) was not statistically significant. In fact, the marginal effect was close to zero and not statistically in all models shown in Table (3) therefore not presented. This evidence fails to support our third hypothesis that poverty in Kenya

\footnotetext{
${ }^{6}$ Question includes: book, radio, television, bicycle, motor vehicle, house, oven, fridge, washing machine, land telephone, land, cattle, and in the question referring to respondent's wealth computer and mobile phones were added. The answers were recorded as either no, yes, or don't know.
} 
was one of the factors that contributed to the electoral violence.

In terms of ethnicity, we find that those of Meru and Kamba origin were less likely to be victims of violence than those of Kikuyu origin (the base group), but no statistical difference in whether a Luo or Kikuyu, the two main opposing ethnicities, were affected. Respondents living in the Central and Eastern provinces were less likely to be victims of violence than those living in Nairobi before the 2007 elections. We find no significant evidence to suggest that the degree of ethnic fragmentation in the area where respondents lived affected the likelihood of being a victim of electoral violence.

We move on to explore the factors that influenced the probability of specifically being physically attacked or injured. To assess this issue we run a second probit model using as a dependent variable whether the respondent "Had been physically attacked or injured because of electoral violence." The results shown in Table (3) under column (2). The sample analyzed is reduced from 1,207 to 982 as there is strong correlation between the likelihood of being victim of physically attacked or injured among the Kamba, Mijikenda and Somalies, hence these observations are dropped from the analysis. Once these observations are dropped the profile of those who were physically attacked or injured suggest that the respondent's ethnicity and wealth level did not affect the chances of being injured or attacked. However the chances of being injured or attacked increased by $9 \%$ if respondents reported "Having heard of gangs connected to politics operating in their communities before the elections". We find no significant evidence to suggest that the degree of ethnic fragmentation in the area where respondents lived affected the likelihood of being physically attacked.

In a third probit model we explore the factors that influenced the probability of suffering a loss in income or assets "because of failed household business (non-agricultural) as a consequence of electoral violence”. The results shown in Table (3) under column (3) show that respondents' chances of having their business fail increased by $10 \%$ if the respondent had "Heard of organized gangs connected to politics operating in their communities before the elections". 
The chances of suffering a loss of income or assets increased by 5\% if they were living in an urban setting probably as violence clustered in urban areas where businesses (non-agricultural) concentrate. The Luos, Luhyas, Kambas and Kissis were less likely to have reported a loss of income or assets because of failed business than the Kikuyus.

\section{Should amnesty be granted?}

Our descriptive analysis suggests that a great proportion of the population (one out of three) were affected by the electoral violence in many ways: personal injury, death of relatives or friends, loss of income or assets, being displaced from home. A current heated debate in Kenya has focused on whether amnesty should be granted to those who committed or instigated electoral violence. To assess the views of our respondents on this matter we asked them "In your view should people who participated in the incidents of violence in the 2007 elections be forgiven, that is given amnesty?”. Using the responses to this question we estimate the probit model shown in eq. (3). As the explanatory variable we use respondent's characteristics, represented by vector $\mathrm{X}_{\mathrm{i}}$ : wealth level, ethnicity, whether was living in an urban area and whether the respondent was victim of violence in a broad sense (having suffered from personal injury, destruction of home, being forced to leave home, damage to personal property, loss of a job, destruction/closure of business, loss of earning from business, friends or relatives died). We also control for the province where the respondent lived right before the elections $P_{i}$, and the degree of ethnic diversity in the area

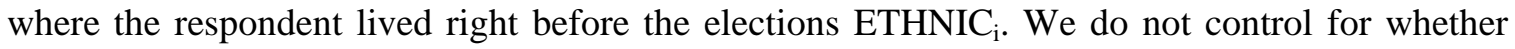
respondent had land disputes or heard of gangs operating in area as these variables are correlated with the probability of being victim of violence.

In Table (3) under column (4) it is shown that the probability of thinking that amnesty should be given is not affected by whether the respondent was a victim in the outbreak of electoral violence. This may appear counter-intuitive, but it is possible that many of the victims of violence resorted to violence themselves (not necessarily to defend themselves), and are therefore 
afraid of being prosecuted if amnesty is not granted. Respondents of Luo, Luhya, Kissi, Kalenjin and other minor ethnic group are more likely to think amnesty should be given than those of Kikuyu origin. The difference in opinions about amnesty across ethnic groups might obey that ODM supporters suffered more arrests than the Kikuyus during the demonstrations and months of post-electoral violence (De Smedt, J. (2009).

$$
\operatorname{Pr}\left(\text { amnesty should be given }_{i}=1\right)=\Phi\left(\alpha+\mathrm{X}_{\mathrm{i}} \beta+\mathrm{P}_{\mathrm{i}} \eta+\mathrm{ETHNIC}_{\mathrm{i}} \delta\right) \quad \text { eq. (3) }
$$

\section{Impact on Social Capital}

Here we focus more closely on assessing some of the consequences of the disputed election on how people relate to each other. For this purpose we run a probit regression using as a dependent variable whether the survey respondent answered that "Since the elections of 2007 the respondent's trust has worsened for people of other ethnic groups". We control for respondent's characteristics (wealth level, ethnicity, whether was victim of violence and living in an urban area), represented by vector $\mathrm{X}_{\mathrm{i}}$, the province where the respondent lived right before the elections $\mathrm{P}_{\mathrm{i}}$, and the degree of ethnic diversity in the area where the respondent lived right before the elections ETHNIC .

$$
\operatorname{Pr}\left(\text { trust got } \text { worse }_{i}=1\right)=\Phi\left(\alpha+\mathrm{X}_{\mathrm{i}} \beta+\mathrm{P}_{\mathrm{i}} \eta+\mathrm{ETHNIC}_{\mathrm{i}} \delta\right)
$$

As shown in Table (3) under column (5) shows that trust for people of other ethnic group was not affected by respondent's wealth level or whether respondent was living in an urban setting. However, having being victim of post-electoral violence increased the probability of not trusting people of other ethnic groups by 7\%. Luhya, Kamba, Meru, Kissi, Kalenjin and Mijikenda are less likely to report that their trust for people of other ethnic group got worse compared to the Kikuyu (the reference group).

In column (6) we instead focus on the factors the probability that respondents answered "Since the elections of 2007 the respondent's trust has worsened for people of his/her ethnic 
group". We find no evidence that having being victim of violence affected the probability of distrusting people of same ethnic group.

To conclude or econometric analysis we estimate a probit model using as a dependent variable whether respondents answered "The extent to which they do business with people from a different tribe to his/hers has deteriorated since the elections". The results of this model, presented in (7), show that the probability of a respondent doing less business with people of other tribes was not affected by respondent's ethnicity (with the exception of the Somalies), by whether respondent was affected by violence or living in urban setting.

\section{Conclusions}

The objective of this article was to investigate of the triggers of the Kenyan electoral violence, its characteristics and consequences. We showed that before the elections there were widespread irregular electoral practices, including instigation of violence. One out of two experienced attempted vote buying, one out of three heard of organized gangs connected to politics instigating violence in their communities and almost one out of six experienced intimidations. The belief that the elections had been stolen was the straw that broke the camel's back triggering the unprecedented levels of violence. However the violence, which affected one out of three Kenyans and the economy in the East Africa region, was rather the explosive result of a combination of historical, economic and political factors. Old grievances such as land disputes became entangled in the outbreaks of electoral violence. We found evidence of politically instigated violence in the form of organized gangs both before and after the elections. As such the chances of being a victim of violence were higher in areas with land conflicts and where politically-connected gangs operated. Institutional failures at the macro-level (weaknesses of the Electoral Commission, the administration of the police, the judiciary system, political parties, among others) were also at the root of the problem contributing to the conflict and the deterioration of trust in institutions and social capital at community level. 
International experience has shown that ethnic conflicts are often the result of the decline of meditating institutions such as political parties as a forum of democratic negotiations and the lack of pre-existing credible commitments across groups (Bardhan, 1997). Political-institutional failures have been especially common in Africa (with extreme examples such as Burundi, Liberia, Rwanda, Somalia and Zimbabwe) as ethnically-based parties in electoral systems where the winner takes it all, tend to obey to 'extreme ethnic demands' (Bardhan, 1997, p.1390). It is then that ethnic demands lessen the potential stabilizing factor of inclusion that democracy aims to achieve.

The nature of much of the electoral-violence potentially calls into question how democracy in Kenya and in general of African countries alike can work when deeply divided by ethnic allegiances. If allegiance is based on ethnic identity the normal beneficial consequences of elections may not hold: elections may fail to discipline governments into improved economic performance. Conversely, they may leave a dysfunctional legacy of violence and uncertainty (Collier et al. 2010).

International evidence provided by Chauvet and Collier (2009) suggests that elections in developing countries only improve policies if they are well-conducted. Hence, from the perspective of Kenya, the contested results and the aftermath of the 2007 election may constitute a setback to what had until then appeared to be a beneficial process of democratization.

So what can Kenya do to continue growing and remain a peaceful democratic country? Some requirements are evident. As the recent experiences of other African countries have shown, it makes little sense to run elections in an environment where violence is openly instigated by politicians. It is crucial then to have an independent electoral commission that is equipped with all the judiciary and other capabilities to guarantee free and fair elections. Reforming the current centralised fiscal system such that it provides inclusion and resources to all, regardless of which party is in power, could also help to reduce much of the disputes and rent-seeking behaviour that 
is currently contributing to conflict. Solving existing land disputes and irregularities, and avoiding them particularly during the elections can also reduce the risk of violence.

It is equally important to restore the rule of law and to prosecute electoral malpractices such as the instigation of violence by political parties or organized gangs, intimidation, vote buying and ultimately the stuffing of ballot boxes. No single person has yet been tried for the electoral violence or the electoral irregularities. Amnesty and oblivion is a way of legitimizing violence. Amnesty is unlikely to help in the reconciliation of Kenyans and in the prevention of the atrocities that Kenya witnessed from reoccurring. It is a matter that Kenya needs to take seriously. Kenya will have to act now or face the consequences, especially so considering that an international predictor of civil conflict is having had a conflict in the past. Because of Kenya's crucial economic role in the East African region, the efforts of preventing a new crisis is no longer reduced to preventing the socio-economic devastation solely of Kenya but beyond her borders.

\section{References}

1. Addison, T. (1998). Rebuilding post-conflict Africa: Reconstruction and reform. Helsinki: Wider/United Nations University.

2. Amnesty International USA, Press Release, $15^{\text {th }}$ Friday 2008. Available at http://www.amnestyusa.org/document.php?id=ENGUSA20080215003\&lang=e

3. Anderson, D. (2002). Vigilantes, violence and the politics of public order in Kenya, African Affairs, 101:(531-55)

4. Alesina, A. F., Devleeschauwer, A., Easterly, W., Kurlat, S., and Wacziarg, R. T. (2003). Fractionalization, Journal of Economic Growth, 8(2): 155-194.

5. Bardhan, P. (1997). Method in the madness? A political-economy analysis of the ethnic conflicts in less developed countries, World Development, 25(9): 1381-98. 
6. Barron, P., Kaisser, K., Pradhan, M. (2009). Understanding variations in local conflict: Evidence and implications from Indonesia, World Development, 37(3): 698-713.

7. BBC News. (2008). AU head urges Kenya peace deal, BBC News, 22 February.

8. Bellows, J., Miguel, E. (2009). War and local collective action in Sierra Leone, Journal of Public Economics, 93(11-12): 1144:57.

9. Bratton, M. (2008). Vote buying and violence in Nigerian election campaigns, Electoral Studies, 27(4): 621-32.

10. Carothers, T. (2007). How Democracies Emerge: The Sequencing Fallacy, Journal of Democracy, 18(1):12-27.

11. Chauvet, L. and Collier, P. (2009). Elections and Economic Policy in Developing Countries, Economic Policy, 24(59):509-50.

12. Commission of Inquiry into Post-Election Violence (CIPEV). (2008). Waki Report, Nairobi.

13. Collier, P. (2000). Rebellion as quasi-criminal activity, Journal of Conflict Resolution, 44(6): 839-53.

14. Collier, P. and Dominic R. (2008). Democracy, Development, and Conflict, Journal of the European Economic Association. 6(2-3): 531-40.

15. Collier, P., Hoeffler, A. and Söderbom, M. (2008). Post conflict risks, Journal of Peace Research, 45(4): 461-78.

16. Collier, P., Gutiérrez-Romero, R., Kimenyi, M. (2010). Democracy and prosperity, in Adam, C., Collier, P. (Eds.) Kenya policies for prosperity, Oxford University Press.

17. Collier, P. and Vicente, P. (2008). Votes and violence: Evidence from a field experiment in Nigeria. Centre for Study of African Economies (CSAE), University of Oxford, working paper, 16.

18. Crilly R. (2008). After violence, Kenya tourism struggles, The Christian Science monitor, 4 March. 
19. De Smedt, J. (2009). 'No Raila, no peace!’ Big man politics and elections violence at the Kibera grassroots, African Affairs, 108/433, 581-98.

20. Durlauf, S.N and Fafchamps, M. (2004). Social capital, NBER, working paper, 10485, Cambridge, MA, NBER.

21. Eiffert, B., Edward M. and Daniel P. (2007). Political Sources of Ethnic Identification in Africa, Afrobarometer working paper No. 89.

22. Fearon, J. and Laitin, D. (2003). Ethnicity, Insurgency and Civil War, American Political Science Review, 97(1): 75-90.

23. Gettleman, J. (2007). Disputed vote plunges Kenya into bloodshed, The New York Times, 31 December.

24. Gurr, T. (2000). People versus states: minorities at risk in the new century. Washington, DC: United States Institute of Peace Press.

25. Holland, H. (2008). Post-poll violence halves Kenya Q1 tourism revenues, Reuters, 2 May.

26. Human Rights Watch, (1993). Divide and rule: Stet-sponsored ethnic violence in Kenya, Human Rights Watch, New York.

27. Kenyan Human Rights Commission, (2001). The right to return: The internally displaced persons and the culture of impunity in Kenya, Kenya Human Rights Commission, Nairobi.

28. Kimani, M. (2008). East Africa feels blows of Kenyan crisis, Africa Renewal, 22(1): 3.

29. Ksoll, C. Macchiavello, R., and Morjaria. A. (2009). Guns and Roses: The Impact of the Kenyan Post-Election Violence on Flower Exporting Firms. Working Paper 2009-06. Center for the Study of African Economies, Oxford University.

30. Mansfield E. and Snyder, J. (2005). Electing to Fight: Why Emerging Democracies Go To War Cambridge: MIT Press.

31. Lindberg, S. (2003). 'It's our time to chop': do elections in Africa feed 
Neopatrimonialism rather than counteract it? Democratization, 10(2): 121-140.

32. Kagwanja, P. M. (1998). Killing the vote: State-sponsored violence and the flawed elections in Kenya. Kenya Human Rights Commission, Nairobi.

33. Kagwanja, P. M. (2001). Politics or marionettes: extra-legal violence and the 1997 elections in Kenya, in Marcel Rutten, Alamin Mazrui and Francois Grignon (eds), Out for the count: The 1997 general elections and prospects for democracy in Kenya. Fountain Publishers Kampala.

34. Kagwanja, P. M. (2003). Facing mount Kenya or facing Mecca? The Mungiki, ethnic violence and the politics of the Moi succession in Kenya, 1987-2002, African Affairs, 102: 25-49.

35. Kalvas, S. (2008). Promises and pitfalls of an emerging research program: The microdynamics of civil war. In S. Kalyvas, I. Shapiro, \& T. Masoud (Eds.), Order, conflict, violence. Cambridge: Cambridge University Press.

36. Ohito D. and Obonyo O. (2010). Chaos: Kibaki, Raila dilemma over allies, The Standard, 4 April.

37. Ongiri, I. (2008). Kenya: I Acted Under Pressure, Says Kivuitu, The Standard, January 2.

38. Orange Democratic Movement (ODM). (2007). Plan for Government General Election 2007. ODM, Kenya.

39. Otieno, D. (2009) I blame Kenyan leaders for Mayhem, The Daily Nation, 5 November.

40. Oyugi, W. O. (1997). Ethnicity in the electoral process: The 1992 general elections in Kenya, African Journal of Political Science, 2(1): 41-69.

41. Peters, P. (2009). Challenges in land tenure and land reform in Africa: Anthropological contributions, World Development, 37(8): 1317-1325.

42. Schaffer, F. (Ed.), (2007). Elections for Sale: the Causes and Consequences of Vote Buying. Lynne Rienner Publishers, Boulder, Colorado. 
43. Soudriette, R. and Pilon, J. (Eds.), (2007). Every Vote Counts: The Role of Elections in Building Democracy, Washington: IFES.

44. The Standard (2009). Arms race' talk risks being self fulfilling, the standard, The Standard, 12 October.

45. Throup, D. and Hornsby, C. (1998). Multi-party politics in Kenya. USA: Ohio University Press.

46. Vicente, P. (2007). Is Vote Buying Effective? Evidence from a Randomized Experiment in West Africa. Center for the Study of African Economies, Working Paper. Oxford University.

47. Wilkinson, S. (2004). Votes and Violence: Electoral Competition and Ethnic Riots in India New York, Cambridge University Press.

\section{Appendix}

Table (1): Characteristics of Pre- and Post- Election Survey Respondents

\begin{tabular}{|c|c|c|c|}
\hline & Pre-election survey & \begin{tabular}{|} 
Post-election survey \\
(including original \\
respondents and \\
replacements)
\end{tabular} & $\begin{array}{l}\text { Post-election survey } \\
\text { (including original } \\
\text { respondents only) }\end{array}$ \\
\hline & Percent & \begin{tabular}{|c|} 
Percent \\
\end{tabular} & Percent \\
\hline Aged 18-26 & 37.67 & 38.26 & 42.0 \\
\hline Wealth asset index $0-40 \%$ & 16.03 & 16.03 & 16.6 \\
\hline Victim of post-electoral violence & 29.29 & 28.90 & 29.4 \\
\hline Male & 52.48 & 52.24 & 54.0 \\
\hline \multicolumn{4}{|l|}{ Ethnicity } \\
\hline Kikuyu & 18.47 & 17.93 & 16.9 \\
\hline Luo & 12.29 & 12.32 & 13.2 \\
\hline Luhya & 15.70 & 14.51 & 20.5 \\
\hline Kamba & 9.36 & 9.70 & 9.3 \\
\hline Meru & 8.14 & 8.31 & 6.3 \\
\hline Kissi & 7.97 & 8.05 & 8.1 \\
\hline Kalenjin & 8.87 & 9.08 & 9.6 \\
\hline Mijikenda & 6.18 & 6.87 & 5.3 \\
\hline Somali & 3.17 & 3.25 & 2.1 \\
\hline Others & 9.85 & 9.98 & 8.7 \\
\hline & 60.93 & 61.40 & 62.2 \\
\hline \multicolumn{4}{|l|}{ Province } \\
\hline Nairobi & 7.03 & 7.83 & 5.9 \\
\hline Central & 9.17 & 8.70 & 7.8 \\
\hline Coast & 12.34 & 13.15 & 10.2 \\
\hline Eastern & 16.54 & 16.46 & 14.2 \\
\hline Nyanza & 15.25 & 14.49 & 15.4 \\
\hline Rift Valley & 24.68 & 24.51 & 25.8 \\
\hline Western & 12.08 & 11.58 & 18.4 \\
\hline North Eastern & 2.91 & 3.27 & 2.3 \\
\hline \multicolumn{4}{|l|}{ Education } \\
\hline No schooling-complete high school & 75.10 & 69.99 & 74.4 \\
\hline More than high school & 24.90 & 28.72 & 25.6 \\
\hline
\end{tabular}

Source: Author pre- and pos- electoral surveys. 
Table (2): Voting intentions by ethnicity according to pre- and post- electoral surveys

\begin{tabular}{l|cccc|cccc} 
& \multicolumn{4}{|c|}{ Pre-Election Survey } & \multicolumn{4}{c}{ Post-Election Survey } \\
& Raila & Mwai & Kalonzo & would not & Raila & Mwai & Kalonzo \\
Odinga & Kibaki & Muzyoka & vote & Odinga & Kibaki & Muzyoka did not vote \\
Kikuyu & 5.7 & 88.1 & 0.4 & 2.2 & 8.4 & 86.5 & 0.8 & 0.8 \\
Luo & 93.4 & 4.0 & 0.0 & 0.7 & 94.2 & 2.7 & 0.0 & 2.4 \\
Luhya & 65.3 & 20.7 & 1.6 & 5.7 & 78.2 & 13.1 & 0.7 & 3.7 \\
Kamba & 0.9 & 19.1 & 73.9 & 0.9 & 8.3 & 28.2 & 59.0 & 3.7 \\
Meru & 6.0 & 89.0 & 2.0 & 0.0 & 6.0 & 90.0 & 0.0 & 1.1 \\
Kissi & 64.3 & 27.6 & 1.0 & 1.0 & 66.4 & 20.9 & 1.1 & 5.1 \\
Kalenjin & 79.8 & 14.7 & 1.8 & 0.9 & 88.0 & 12.0 & 0.0 & 0.0 \\
Mijikenda & 60.5 & 25.0 & 3.9 & 2.6 & 75.1 & 16.8 & 1.5 & 1.4 \\
Somali & 35.9 & 56.4 & 2.6 & 0.0 & 68.8 & 13.7 & 6.7 & 4.3 \\
Others & 57.0 & 32.2 & 1.7 & 1.7 & 65.9 & 28.9 & 0.8 & 2.8 \\
\hline National Average & 46.1 & 39.1 & 8.1 & 2.0 & 52.9 & 35.4 & 6.5 & 2.3
\end{tabular}

Source: Author pre- and pos- electoral surveys.

Figure (1): Victims of electoral violence

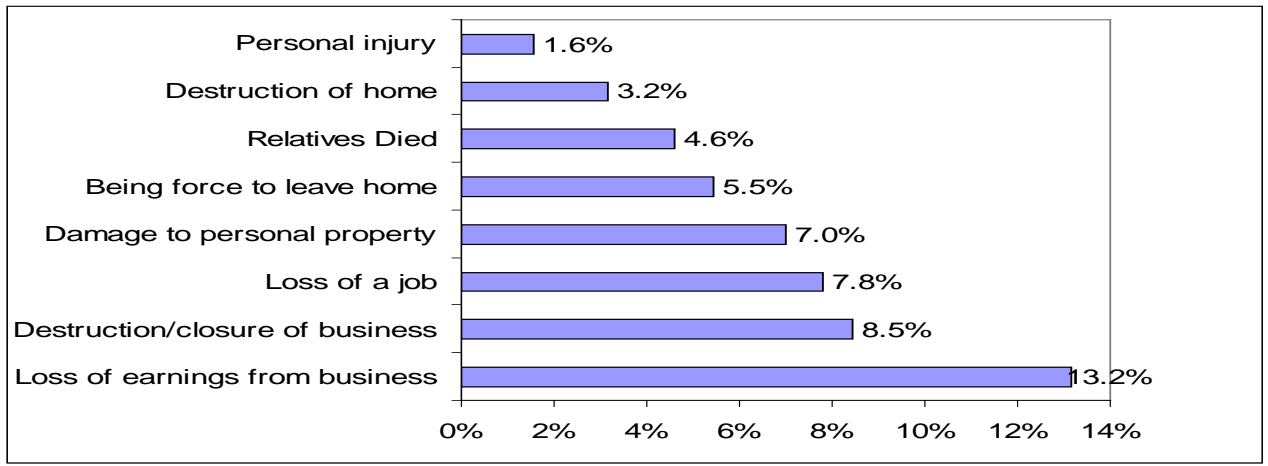

Source: Author pre- and pos- electoral surveys.

Figure (2): What did you do in response to the acts of violence?

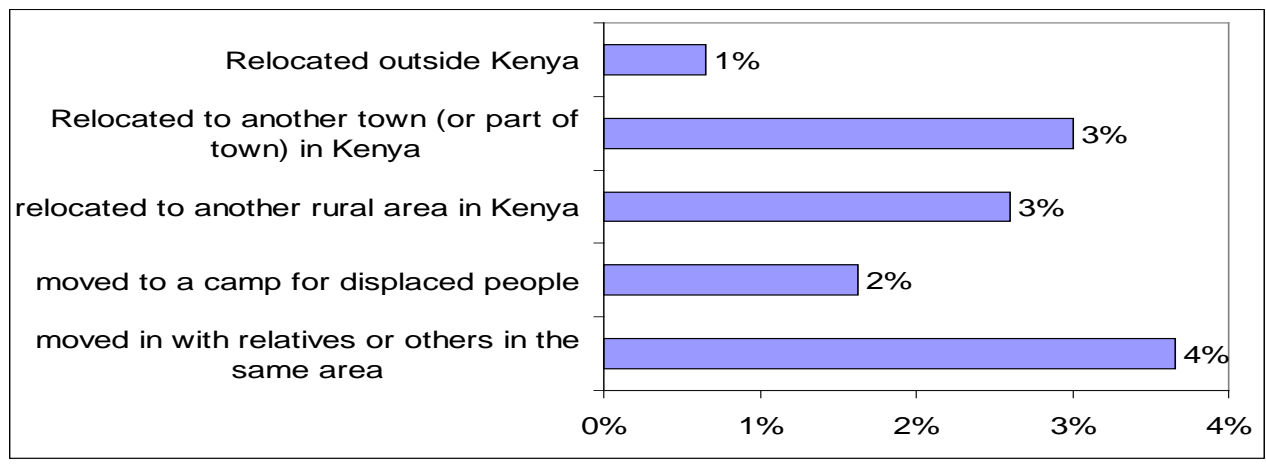

Source: Author pre- and pos- electoral surveys. 
Figure (3): Distribution of victim's electoral violence by province

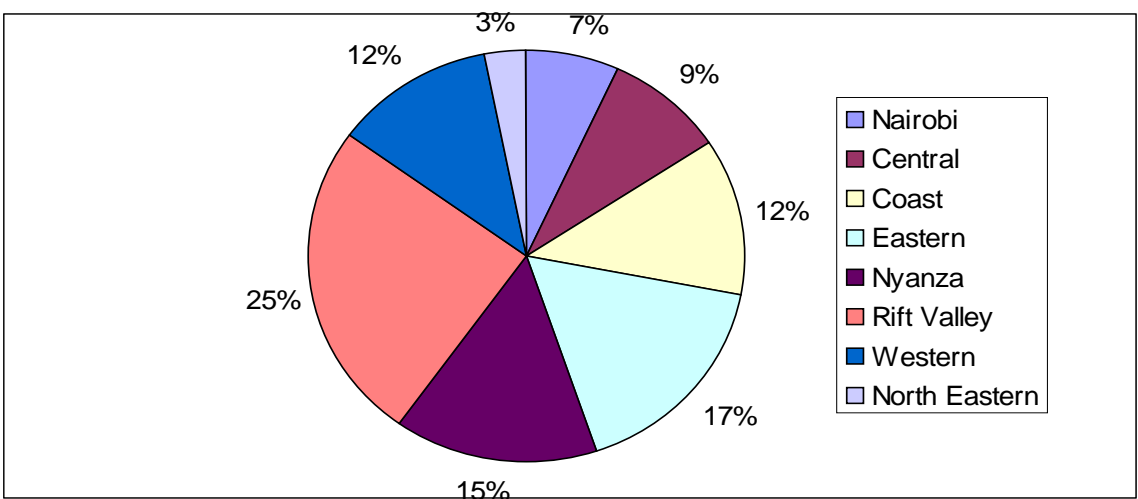

Source: Author pre- and pos- electoral surveys.

Figure (4): Has trust among Kenyans changed since the elections?

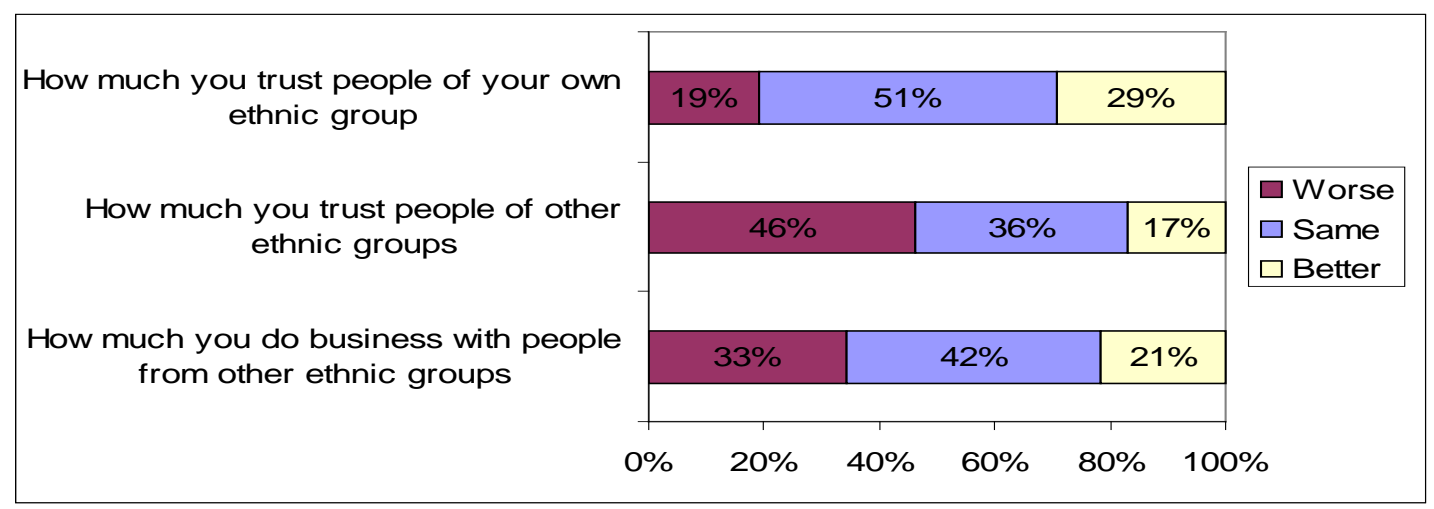

Source: Author pre- and pos- electoral surveys. 
Table (3): Profile of victims of violence and consequence of violence

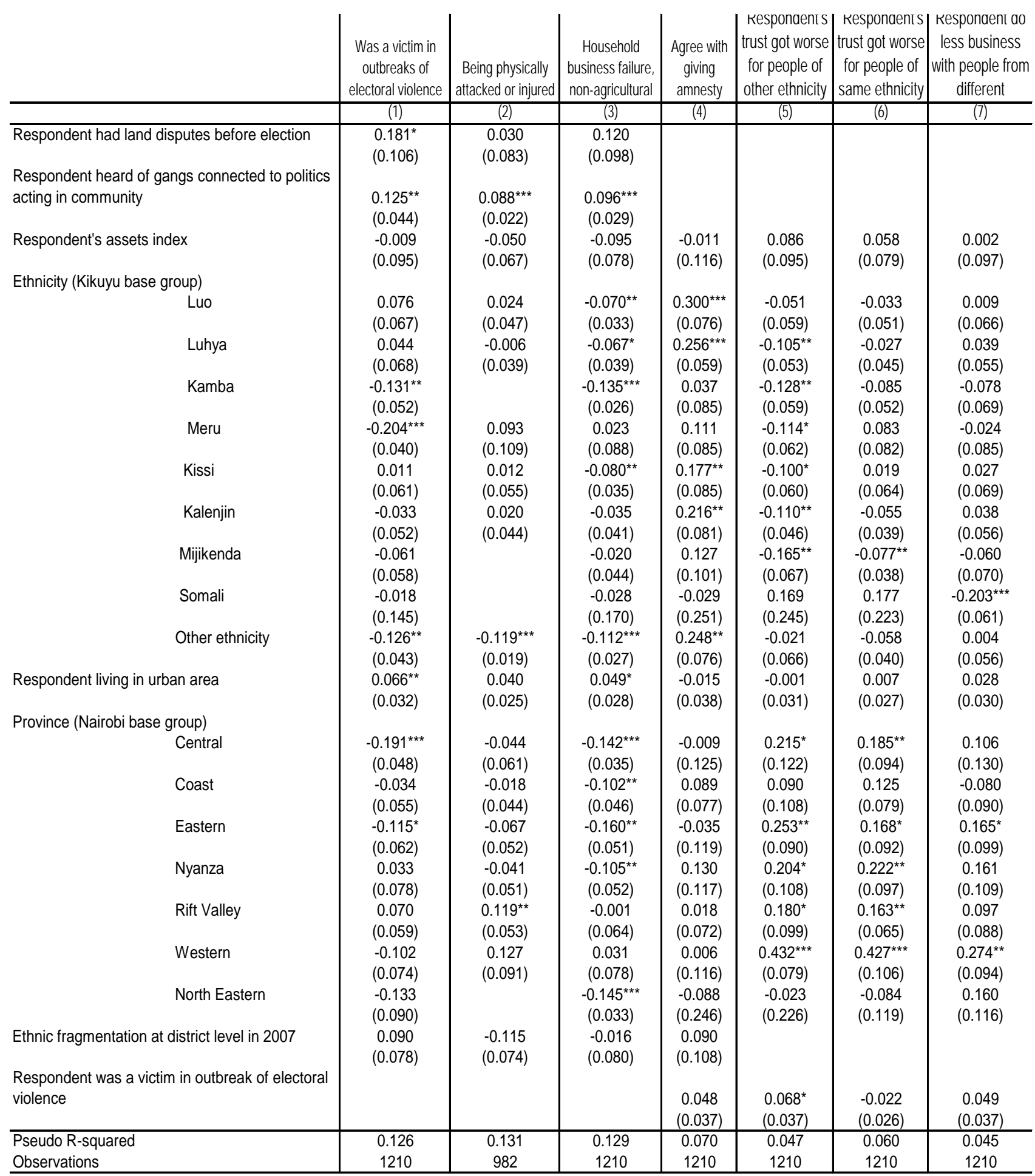

Note: Coefficients as marginal effects. $d F / d x$ is for discrete change of dummy variable from 0 to 1 .

Significance Level, $* p<0.10,{ }^{* *} p<0.05, * * * p<0.001$. Robust standard errors, clustered at constituency

level, are shown in parentheses. 